\title{
Guillain-Barré Syndrome, Before and After Zika
}

\author{
Luis Del Carpio-Orantes Jesús Salvador Sánchez-Díaz
}

\author{
${ }^{1}$ Department of Internal Medicine and Critical Medicine, Delegation \\ Veracruz North, Mexican Institute of Social Security, Veracruz, \\ Mexico
}

J Neurosci Rural Pract 2019;10:567-568

After the invasion of the Zika virus to American lands following the route of dissemination left by Chikungunya in 2015, an increase in acute neurological syndromes was noted, among them the so-called Guillain-Barré syndrome, which is characterized as the main current cause of flaccid paralysis as well as being an acute demyelinating polyneuropathy. After the outbreak of Zika in the Americas, incidences as high as 400 and $800 \%$ of the expected cases were reported, mainly in South America and the Caribbean.

Prior to this colonization by arboviruses hitherto unknown in America, Guillain-Barré syndrome was considered an entity with a low global incidence in the range of 0.6 to 4 cases per 100,000 inhabitants. It usually without distinction of gender and in two predominant age groups: 15 to 34 years and 60 to 74 years. Regarding the etiological agents, the main ones identified previously were Campylobacter jejuni (20-50\%), Cytomegalovirus (5-22\%), Haemophilus influenzae (2-13\%), Epstein-Barr virus (10\%), and Mycoplasma pneumoniae (5\%). In addition to infectious agents, other related conditions are surgeries, vaccines, and injuries. The predominant neuroconduction pattern was axonal (acute motor axonal neuropathy or acute motor sensory axonal neuropathy) both in America and in Europe and some Asian regions, which conferred poor functional and vital prognosis. ${ }^{1-3}$

After the arrival of Zika and after declaring a neurotropic virus due to the high incidence of cases of microcephaly (now called congenital syndrome due to Zika) and Guillain-Barré syndrome, according to a bibliometric study, the overall incidence of these cases due to recent Zika infection (from South America to Mexico) was 42\%, although the incidence of Zika was very variable even in the same geographical area, being from 0 to $100 \%$; the estimated prevalence according to a meta-analysis was $1.23 \%$. In contrast, the most frequent neuroconduction pattern was acute inflammatory demyelinating polyneuropathy, which, according to bibliographic records, has a better functional and vital prognosis, recovering more quickly and in many cases without sequelae (-Table $\mathbf{1}$ ).

In a more delimited way, in Mexico, the incidence of cases associated with Zika was very low (5.8\%); in contrast, other neurotropic infectious agents were identified: dengue, chikungunya, herpes, enterovirus, hepatitis B and even more relevant, the identification of

DOI https://doi.org/

10.1055/s-0039-1697564

ISSN 0976-3147.
Address for correspondence Luis Del Carpio-Orantes, InstitutoMexicano del Seguro Social, Alley 12 de Octubre 603, Center, Veracruz, Mexico, ZC 91900 (e-mail: neurona23@hotmail.com).

Table 1 Main differences of Guillain Barre syndrome, before and after zika

\begin{tabular}{|l|l|l|}
\hline & Before Zika & After Zika \\
\hline $\begin{array}{l}\text { Predominant } \\
\text { neuroconduction } \\
\text { pattern }\end{array}$ & AMAN & AIDP \\
\hline Etiological agents & $\begin{array}{l}\text { Campylobacter } \\
\text { jejuni } \\
\text { Cytomegalovirus } \\
\text { Haemophilus } \\
\text { influenzae } \\
\text { Epstein-Barr } \\
\text { virus } \\
\text { Mycoplasma } \\
\text { pneumoniae }\end{array}$ & $\begin{array}{l}\text { Zika } \\
\text { Dengue } \\
\text { Chikungunya } \\
\text { Enterovirus } \\
\text { Herpes } \\
\text { Hepatitis A-E } \\
\text { Campylobacter jejuni }\end{array}$ \\
\hline Treatment & $\begin{array}{l}\text { Intravenous } \\
\text { immuno- } \\
\text { globulin or } \\
\text { plasmapheresis }\end{array}$ & $\begin{array}{l}\text { Intravenous } \\
\text { immunoglobulin or } \\
\text { plasmapheresis }\end{array}$ \\
$\begin{array}{l}\text { Bad, because } \\
\text { of the predom- } \\
\text { inant axonal } \\
\text { involvement } \\
\text { According to } \\
\text { the promptness } \\
\text { of treatment } \\
\text { initiation }\end{array}$ & $\begin{array}{l}\text { Good most of the } \\
\text { time, according to } \\
\text { the promptness of } \\
\text { treatment initiation }\end{array}$ \\
\hline Prognosis
\end{tabular}

Abbreviations: AIDP, acute inflammatory demyelinating polyneuropathy; AMAN, acute motor axonal neuropathy.

Campylobacter cases that in contrast to common campylobacteriosis, these were not always presented with diarrheal or enteral syndrome, hypothesizing that probably the neurological syndrome was the primary manifestation of this infection.

Despite all the documentary work done so far, the full causal relationship between Zika and Guillain-Barré is not clear, nor has it been possible to clarify why the incidences of the syndrome increased so exponentially in several latitudes of the American continent. ${ }^{4,5}$

Following the information obtained in a global way, the following points of good practice are recommended for a better diagnosis and treatment of patients affected by GuillainBarré syndrome: 
- All acute neurological symptoms that meet the clinical criteria of Asbury-Cornblath (asymmetric paralysis and areflexia) should be treated as Guillain-Barré syndrome until proven otherwise.

- Take into account that there are atypical variants such as Miller-Fisher syndrome, pharyngo-cervical-brachial weakness, facial diplegia, Bickerstaff encephalitis, among others.

- Any case of Guillain-Barré syndrome should be protocolized according to Brighton criteria, trying to perform a diagnostic protocol that includes cerebrospinal fluid analysis, neuroimaging studies, and nerve neuroconduction

An infectious protocol should be performed that includes viral and bacterial agents with proven neurotropism, integrating endemic or tropical zones, serologies, and molecular studies of dengue, Zika, and chikungunya. Likewise, the importance of identifying the causative agents is that some active infections are susceptible to specific treatment (herpes, Cytomegalovirus, hepatitis, campylobacter, influenza, and human immunodeficiency virus)

- For a better serological scrutiny of arboviruses, it is recommended to use reverse transcription polymerase chain reaction techniques from day 0 to 7 and later immunoglobulin $\mathrm{M}$ determination; in regions where there are infections by other arboviruses and there may be immunological cross-reactions between arboviruses (dengue, Zika, mayaro, chikungunya, oropouche, and yellow fever), it is recommended to perform the neutralization technique by plate reduction to elucidate which is the arboviral agent involved

- Pharmacological treatment should be initiated as soon as the suspicion of Guillain-Barré syndrome is established, with intravenous immunoglobulin or plasmapheresis, the main lines of treatment. In the same way, concomitant therapies such as physical therapies and neuromuscular rehabilitation. The functional and vital prognosis of the patient depends on the promptness of the diagnosis and the establishment of the treatment

- Use scales of functionality such as Hugues, medical research council, Erasmus (EGOS-EGRIS), to define the degree of affectation and its recovery after the treatment provided

- Remember that the management of these patients must be multidisciplinary for a better resolution.

\section{Funding}

None.

\section{Conflict of Interest}

None declared.

\section{References}

1 del Carpio-Orantes L. [Emerging Arboviroses in Mexico: chikunguña and zika]. Rev Med Inst Mex Seguro Soc 2016;54(3):278-279

2 Del Carpio-Orantes L. [Zika, a neurotropic virus?]. Rev Med Inst Mex Seguro Soc 2016;54(4):540-543

3 Secretaría de Salud. Diagnóstico y Tratamiento del Síndrome de Guillain Barré en el Segundo y Tercer Nivel de Atención. Ciudad de México: Secretaría de Salud; 2016

4 Barbi L, Coelho AVC, Alencar LCA, Crovella S. Prevalence of Guillain-Barré syndrome among Zika virus infected cases: a systematic review and meta-analysis. Braz. J Infect Dis 2018;22(2):137-141

5 Dias ÍKR, Sobreira CLDS, Martins RMG, et al. Zika virus: a review of the main aspects of this type of arbovirus. Rev Soc Bras Med Trop 2018;51(3):261-269 